\title{
Enhancement of Azo Dye Degradation by Chemical and Physical Mutagenesis in Identified Bacillus: An Influential Source of Industrial Dye Degradation
}

\author{
V. Pushpa ${ }^{1 *}$ K. Yogendra ${ }^{1}$, K. M. Mahadevan ${ }^{2}$ and M. Mahesh ${ }^{3}$ \\ ${ }^{1}$ Department of P. G. Studies and Research in Environmental Science, Kuvempu University, \\ Jnanasahyadri, Shankaraghatta, Shivamogga (Karnataka), India \\ ${ }^{2}$ Department of P. G Studies and Research in Chemistry, P.G. Centre Kadur, Kuvempu \\ University, Kadur (T), Chickmagalur (D) (Karnataka), India \\ ${ }^{3}$ Azyme Bioscience Pvt Ltd, Bangalore (Karnataka), India \\ *Corresponding author
}

\section{A B S T R A C T}

\section{Keywords}

Bacillus,

Bioremediation, degradation, UVrays $\mathrm{X}$-rays

\section{Article Info}

Accepted:

15 February 2020

Available Online:

10 March 2020
Modern industrialization causes major environmental pollution and degradation. The Environmental changes results the genomic instability in human cells, bacterial cells and yeast cells. Due to high rate of genetic instability, mutation rate has become high and it induces the potential to adaptevolution for living cells. There are several physical and chemical mutagenic agents are available which can induce mutation in genetic materials. This paper exposed to isolate azo dye degradation bacteria from dye-contaminated soil and induction of mutation using X-rays, ultraviolet (UV) radiation and ethidium bromide to determine the highest dye-degrading mutant with higher dye degrading potentials, which could be employed in the bioremediation of industrial dyes. In this study, mutation was performed on the Bacillus species through physical (UV, X-rays) and chemical (ethidium bromide) mutagenic agents. The results revealed that, mutagenesis of bacteria by UV radiation increases the degradation ability of native bacterial isolates. It reflected that, gene specific mutation enhanced the degradation ability of bacteria and can be used for the development of novel remediation strategies. The growth and azo dye degradation capacity of the isolated strain was examined and compared with the mutated strain. The major purpose of this study was to demonstrate the effectiveness and the pathway used for dye degradation in the isolated strain and its mutant variant. The present study can be applicable to enhance the industrial dye degradation by using the mutated strain of bacillus.

\section{Introduction}

Rapid industrialization leads to environmental pollution. Early studies have been proved that environmental stress results in the induction of genomic instability in bacteria, yeast, and also human cells that genomic instability in organisms can able to cause mutation and this is how the organism gains the potential to adaptive evolution (Galhardo et al., 2007).In 
many research fields, the mutation has been practiced very often as a strain improvement technique since the late 1930s because of its specificity, cost-effectiveness, and can be applied directly (Rowlands, 1984). It was proved that, the efficiency of bacterial and fungal strains has been improved extensively by mutation using physical and chemical agents (Baltz, 1986). There is a range of mutagenic agents and they are selected based on their availability, simplicity of technique. Mutagens are highly toxic, so safety from the mutagen is another essential factors, which are to be considered while selecting a mutagen (Hopwoods, 1970;Okafor, 1987). In the biodegradation of azo dyes, mutants play an essential role in enhancing the required potential for degradation. Mutations can be induced in genetic material by exposure to physical or chemical mutagens.

Ultraviolet (UV) irradiation is one of the physical mutagens, which is frequently used to generate mutant strains by forming pyrimidine dimerization and cross-links in DNA because its wavelengths were preferentially absorbed by nucleotides of DNA and by aromatic amino acids of proteins, so it has significant biological and genetic effects (Saghatchi, 2016).

$\mathrm{X}$-ray is one among the physical mutagens and is electromagnetic waves with short wavelength and high energy (AlsNielsen et al., 2011). The radiation energy is transferred through the atoms and leads to ionisation in matter. Ionising radiation has many shortterm and late hazardous effects (Hall et al., 2006). Several studies have demonstrated metabolism promotion in microorganisms, plants, invertebrates and laboratory animals by low-level ionising radiation. X-rays being ionising irradiation, cause ionisation in the molecule of DNA, thereby producing reactive radicals that cause changes in the DNA or out precisely kill the cells (Okafor, 1987;
Feinendegen et al., 2014; Robertson et al., 2012; Ristow et al., 2011).

Ethidium bromide (EtBr) is still the most widely used chemical mutagen in the laboratories because of its higher sensitivity in nucleic acid detection. EtBr is a robust potent mutagen that can cause a high frequency of frame-shift mutation to the microorganisms when it is processed by rat liver extract (Singer et al., 1999; Ohta et al., 2001; MacGregor and Johnson, 1977).This research was thus aimed to isolate azo dye degrading bacteria from dye-contaminated soil, initiating mutation using X-rays, ultraviolet (UV) radiation and ethidium bromide determining the mutant with higher dye degrading potentials, which could be employed in the bioremediation of industrial dyes.

\section{Materials and Methods}

The mutation was performed on the identified Bacillus species (Pushpa et al., 2019)through physical (UV, X-rays) and chemical (ethidium bromide) mutagenesis process.

\section{Mutagenesis with UV radiation}

Mutation with ultraviolet (UV) radiation of wavelength ranging from 230-270nm was carried out in a UV chamber. Bacillus colonies were spread on LB agar plates and exposed to UV radiation for different time intervals such as 5, 10, 1520 and 25 minutes keeping at a distance of $40 \mathrm{~cm}$ and incubated at $37^{\circ} \mathrm{C}$. After incubation, the colonies were transferred to $100 \mathrm{~mL}$ of $\mathrm{M} 9$ media with red and blue dye and incubated at $35^{\circ} \mathrm{C}$ for $48 \mathrm{~h}$ for the growth of mutants. Degradation was assessed at every $24 \mathrm{~h}$ time intervals upto 5 days and degradation activity was measured spectrophotometrically at $580 \mathrm{~nm}$ for red dye and $540 \mathrm{~nm}$ for blue dye. 


\section{Mutagenesis with X-rays}

Using a modified method of Lederberg and Lederberg (1952), $100 \mathrm{~mL}$ of LB agar plates with pure colonies of Bacillus species were exposed to different intensities of X-rays such as R1, R2, R3, R4 and R5. After the exposure, the cultured colonies were transferred to 100 $\mathrm{mL}$ of M9 media with red and blue dye and incubated $35^{\circ} \mathrm{C}$ for 48 hours for the growth of mutants. Degradation activity was measured spectrophotometrically at every $24 \mathrm{~h}$ time intervals upto 5 days and at $580 \mathrm{~nm}$ for red dye and $540 \mathrm{~nm}$ for blue dye.

\section{Mutagenesis with ethidium bromide treatment}

Bacillus suspension was inoculated in $1 \mathrm{~mL}$ of LB broth with different concentrations of ethidium bromide ranging from $10-50 \mu \mathrm{g} / \mathrm{mL}$ and incubated at $37^{\circ} \mathrm{C}$ for $24 \mathrm{~h}$. After the incubation, the mutated organisms were inoculated in M9 broth along with the azo dyes and assessed for degradation spectrophotometrically at $580 \mathrm{~nm}$ for red dye and $540 \mathrm{~nm}$ for blue dye.

\section{High performance of liquid chromatography (HPLC) Analysis}

The obtained decolorization was estimated by using HPLC (MA 01757 US). Water 510, C18 column (4.6 diameter, 250mm length). Mobile phase (acetonitrile: water, 70:30), flow rate $1 \mathrm{ml} / \mathrm{min}$, pressure $1200 \mathrm{psi}$, injection volume $20 \mu \mathrm{L}$, UV detector $282 \mathrm{~nm}$ was used for analysis. Qualitative analysis was done based on RT value, and quantitative analysis was done based on the area.

\section{Results and Discussion}

Improvement of microbial strains for the overproduction of industrial products has been the need of all industrial fermentation process. Those improved strains have the advantage of the reduction in the cost of the process, and also they possess some desirable characteristics, which result in a significant increase in productivity.

Effectiveness of mutagens on Bacillus species such as physical mutagen including UV radiation showed $38 \%$ of degradation on exposure of $15 \mathrm{~min}$ (Fig. 1) and X-rays showed 39\% with R4 exposure (Fig. 2) and chemical mutagen and chemical mutagenethidium bromide showed $40 \%$ of degradation with $20 \mathrm{~min}$ of exposure time (Fig. 3) for red dye and for blue dye $34 \%$ in 5 min of UV exposure, $35 \%$ in $25 \mathrm{RT}$ X-ray exposure and $36 \%$ in 40 min EtBr exposure. Hence in the present investigation, it was demonstrated that, the mutation has improved degradation ability of Bacillus species. We can have a hope that, high yielding mutant strain of the Bacillus species can be exploited commercially for large-scale industrial usage in the reduction of pollution. In support of this statement, many workers reported the enhanced activity of the microorganisms in case of mutation.

Mandalaywala and Trivedi, (2016) reported that, petroleum degradation ability was enhanced by UV radiation among 5 mutant strains of Pseudomonas aeruginosa strain JQ41 has the highest potential to degrade petroleum products. Alsulami et al., (2014) mutated 4 bacterial species Aeromona shydrophila, Bacillus subtilis, Pseudomonas aeruginosa and Pseudomonas fluorescens by exposing bacteria to Millard reaction products.

These mutants showed enhanced biodegradability potential of crude oil. Bacillus subtilis mutants increased biodegradation from $60.6 \%$ to $92.5 \%$ and an increase in the degradation of crude oil by the other three mutant species ranged from 37 to 
72.3\%. Chaudhari and Fulekar, (2013) reported that, UV mutated Pseudomonas pseudoalcaligenes MHF ENV mutant enhanced degradation of dibutyl phosphate from 30 to $90 \%$ over 6 days. Bacillus amyloliquefaciens were exposed to doses of gamma radiation with an increase in radiation dose, the viable count of these bacteria decreased. Mutant did not show increase growth on naphthalene than the parent strain but showed enhanced growth on phenanthracene, anthracene, pyrene and benzo-anthracene (Partila, 2013).

Chen et al., (2011) observed that, in the soil contaminated with viscous oil, the microbial consortium degraded oil by about $49.22 \%$ within a week; however UV mutant single strain enhanced degradation of viscous oil from $41.83 \%$ to $52.42 \%$ for 1 week. Kumar et al., (2010) reported that, mutagenesis of bacteria inducted an increase in petroleum degradation activity in 3 bacteria Micrococcus species, Staphylococcus species and Pseudomonas species mutant. Pseudomonas species mutant was the most promising for petroleum oil-degrading activity.

\section{High performance liquid chromatography (HPLC) analysis}

Based on the HPLC graph, retention time (RT) of the control was 2.07 and the decolourised sample was 2.08. RT of the sample also resembles with the RT of control. The area of the standard is $57.14 \mathrm{mV}$, and the decolourised sample is 40.77. Based on the area percentage of degradation shows $40 \%$ for red dye.

Based on the HPLC graphical representation, control (without degradation) showed RT (2.5) and the area was $47.221 \mathrm{mV}$. After degradation sample was analyzed RT was the same $(2.5)$, but the area was $30.21 \mathrm{mV}$. It is indicating that approximately $36 \%$ of blue dye was degraded and also it is confirmed by spectrophotometric reading (Fig. 4, 5). Similar to our results, Madhuri et al., (2018) identified the dye degradation by comparison of the retention time in samples with the standard the degraded sample Bacillus cereus confirming the degradation of remazol red RB. The significant absence of the peaks found in the dye (control) sample and the presence of new peaks in the degraded metabolites with new retention times support the biotransformation of parent dye into molecules.

Rajeshwari et al., (2011) monitored the biodegradation using HPLC appearance of new peaks and disappearances of specific peaks were observed which showed that either there is biodegradation or biotransformation of the azo dye. The sample treated with Hafiaalvei obtained the peak with the shortest RT of 1.98 .

\section{Pearson's correlation interpretation red dye}

Pearson correlation coefficient was tested for the correlation of the different factors to the rate of degradation. In the case of red dye, the concentration of dye, $\mathrm{pH}$ and RPM are strongly correlated with incubation time for the degradation of dye (Table 1; Table 2).

However, metal ion and ethidium bromide did not correlate with incubation time. Pearson's correlation analysis also suggested the concentration of the dye does not correlate with any other parameters studied. It indicated that only one parameter did not influence dye degradation, but all other parameters were also important.

Rate of dye degradation is strongly correlated for RPM and $\mathrm{pH}$. Optimum $\mathrm{pH}$ and RPM can increases the degradation rate and $\mathrm{pH}$ are correlated positively in all the parameters 
except metal ion and ethidium bromide. Temperature was also one of the critical parameters that are positively correlated with all the parameters except metal ion and ethidium bromide. The correlation coefficient indicated that metal ion does not correlate with any parameter positively. Furthermore, it showed that metal ion concentration does not influence the rate of degradation. It showed a negative correlation with all parameters studied. Nitrogen and carbon sources positively correlated with all parameters except metal ions. Treating with X-ray is positively correlated with all except the concentration of dye. Time of UV exposure was positively correlated with all parameters except the concentration.

\section{Blue dye}

Similar to red dye, Pearson's correlation was also tested for blue dye. Incubation time is strongly correlated with the concentration of dye, $\mathrm{pH}$, temperature and mutation treatment with UV, X-ray and ethidium bromide (Table

2). Nevertheless, it was not strongly correlated with RPM, carbon and nitrogen source and metal ion.

The concentration of dye is strongly correlated with all parameters except carbon and nitrogen source that was negatively correlated and metal ion and RPM are not much correlated. Temperature was strongly correlated with $\mathrm{pH}$ but it did not correlated with carbon and nitrogen source and metal ion.

But $\mathrm{pH}$ was negatively correlated with RPM and carbon and nitrogen source and positively correlated with other parameters. RPM has strongly influenced the rate of degradation with carbon, nitrogen source, metal ions and slightly influenced mutation parameters. When carbon and nitrogen source were correlated with other parameters, incubation time and RPM are positively correlated and negative correlation showed with $\mathrm{pH}$, temperature and concentration of dye. Supply of metal ions strongly influenced the dye degradation with carbon and nitrogen source and was negatively correlated with temperature and $\mathrm{pH}$.

Interestingly, mutation with mutagens like UV light, X-ray and ethidium bromide strongly correlate with the degradation, except carbon and nitrogen source. When red and blue dye degradation is considered together, metal ion concentration does not play an important role in dye degradation in case of red dye. But metal ion concentration influences the dye degradation in blue dye.

At the same time, incubation time plays important role in dye degradation in both red and blue dyes. RPM plays important role in red dye but not in blue dye. Carbon and nitrogen source in both the cases not so much influenced the degradation. Treatment with mutagens like UV, X-ray and ethidium bromide increases the rate of degradation in blue dye, and it does not show much significance in red dye. The result showed that mutation studies on Bacillus species in the present study influenced the rate of degradation in blue dye but not on red dye. The possible reason behind this was the chemical nature of both the dyes. The same mutation cannot influence the degradation of chemically different dyes.

Similarly, Pant et al., (2008) observed a highly significant correlation $(\mathrm{r}=0.78$, $\mathrm{p}<0.001)$ between color and COD of dye solutions was recorded. Thus, a readily available carbon and nitrogen source was imperative to enhance the bioremediation activity of this fungus, which has been the most suitable for synthetic dyes and textile industry wastewater treatment. 
Table.1 Pearson's correlation interpretation of red dye

\begin{tabular}{|c|c|c|c|c|c|c|c|c|c|c|c|}
\hline Treatments & $\begin{array}{c}\text { Conc. Incubation } \\
\text { time }\end{array}$ & Conc. (mg) & pH & $\begin{array}{l}\text { Temp } \\
\left({ }^{\circ} \mathrm{C}\right)\end{array}$ & RPM & $\begin{array}{l}\text { Carbon } \\
\text { source }\end{array}$ & $\begin{array}{l}\text { Nitrogen } \\
\text { source }\end{array}$ & $\begin{array}{l}\text { Metal } \\
\text { ions }\end{array}$ & $\begin{array}{c}\text { UV } \\
\text { exposure } \\
\text { time }\end{array}$ & $\begin{array}{c}\text { x-rays } \\
\text { exposure }\end{array}$ & $\begin{array}{c}\text { Ethidium } \\
\text { bromide } \\
\text { exposure }\end{array}$ \\
\hline Incubation Time 1 & 1 & 1 & \multirow[t]{3}{*}{1} & \multirow[t]{3}{*}{1} & & & & & & & \\
\hline Conc. (mg) & 1 & 1 & & & & & & & & & \\
\hline pH & 1 & -0.67 & & & & & & & & & \\
\hline $\operatorname{Temp}\left({ }^{\circ} \mathrm{C}\right)$ & 0.14 & -0.09 & 0.14 & 1 & 1 & & & & & & \\
\hline RPM & 1 & -4.70 & 1 & 1 & 1 & & & & & & \\
\hline Carbon source & 0.57 & -0.35 & 0.57 & 0.57 & 0.78 & 1 & & & & & \\
\hline Nitrogen source & 0.34 & -0.02 & 0.34 & 0.34 & 0.41 & 0.41 & 1 & & & & \\
\hline Metal ions & -0.75 & -0.23 & -0.74 & -0.23 & -0.74 & -0.74 & -0.74 & 1 & & & \\
\hline UV exposure time & 0.20 & -0.35 & 0.20 & -0.35 & 0.52 & 0.52 & 0.52 & 0.52 & 1 & & \\
\hline X ray & 0.54 & -0.16 & 0.54 & -0.16 & 0.72 & 0.72 & 0.72 & 0.72 & 0.54 & 1 & \\
\hline $\begin{array}{c}\text { Exposure } \\
\text { Ethidium bromide }\end{array}$ & -0.55 & -0.74 & -0.55 & -0.74 & 0.04 & 0.04 & 0.04 & 0.04 & -0.55 & -0.55 & 1 \\
\hline
\end{tabular}

Table.2 Pearson's correlation interpretation of blue dye

\begin{tabular}{|c|c|c|c|c|c|c|c|c|c|c|c|}
\hline Treatments & $\begin{array}{c}\text { Conc. } \\
\text { Incubation } \\
\text { time }\end{array}$ & Conc. (mg) & pH & $\begin{array}{c}\text { Temp } \\
\left({ }^{\circ} \mathrm{C}\right)\end{array}$ & RPM & $\begin{array}{l}\text { Carbon } \\
\text { source }\end{array}$ & $\begin{array}{l}\text { Nitrogen } \\
\text { source }\end{array}$ & $\begin{array}{c}\text { Metal } \\
\text { ions }\end{array}$ & $\begin{array}{c}\text { UV } \\
\text { exposur } \\
\text { e time }\end{array}$ & $\begin{array}{c}\text { x-rays } \\
\text { exposure }\end{array}$ & $\begin{array}{l}\text { Ethidium } \\
\text { bromide } \\
\text { exposure }\end{array}$ \\
\hline Incubation Time 1 & 1 & & & & & & & & & & \\
\hline Conc.(mg) & 0.98 & 1 & & & & & & & & & \\
\hline pH & 0.92 & 0.96 & 1 & & & & & & & & \\
\hline $\operatorname{Temp}\left({ }^{\circ} \mathrm{C}\right)$ & 0.92 & 0.96 & 0.99 & 1 & & & & & & & \\
\hline RPM & 0.14 & 0.00 & -0.25 & -0.25 & 1 & & & & & & \\
\hline Carbon source & 0.13 & -0.00 & -0.25 & -0.26 & 0.99 & 1 & & & & & \\
\hline Nitrogen source & 0.14 & -0.00 & -0.25 & -0.25 & 0.99 & 0.99 & 1 & & & & \\
\hline Metal ions & 0.18 & 0.04 & -0.20 & -0.20 & 0.99 & 0.99 & 0.99 & 1 & & & \\
\hline UV exposure time & 0.99 & 0.98 & 0.91 & 0.91 & 0.15 & 0.14 & 0.15 & 0.19 & 1 & & \\
\hline X ray & 0.99 & 0.98 & 0.91 & 0.91 & 0.15 & 0.14 & 0.15 & 0.19 & 0.99 & 1 & \\
\hline Exposure Ethydium bromide & 0.999 & 0.98 & 0.91 & 0.91 & 0.16 & 0.15 & 0.16 & 0.21 & 0.99 & 0.99 & 1 \\
\hline
\end{tabular}




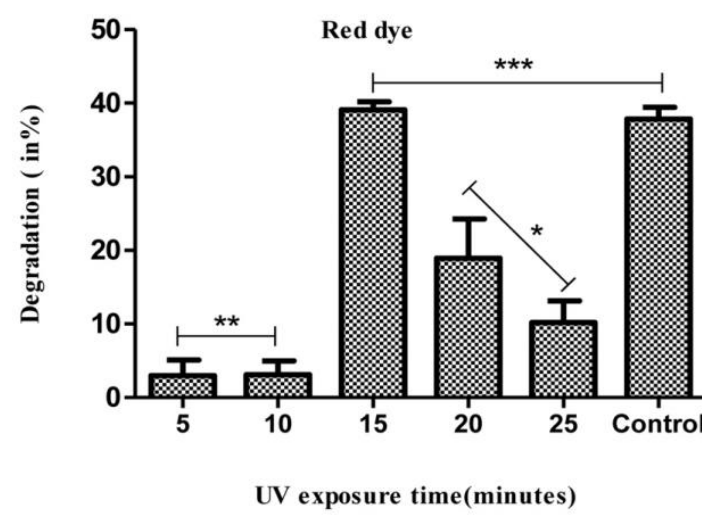

(A)

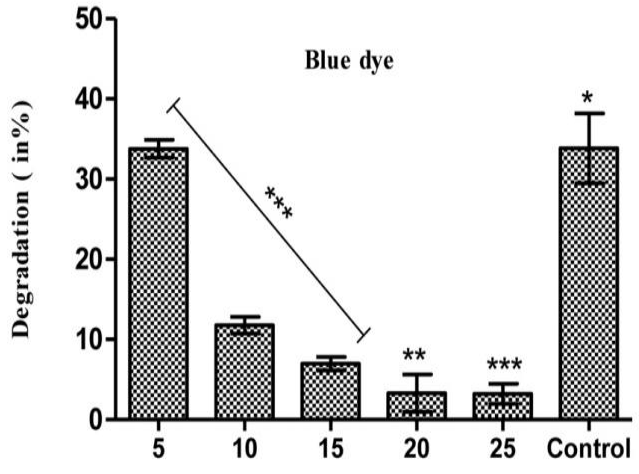

UV Exposure time (minutes)

(B)

Fig.1 Mutagenesis with UV radiation in (A) red dye and (B) blue dye

'Bars' represent the mean $\pm \mathrm{SE}$ from three independent experiments, 'star' indicates significant difference at $\mathrm{p}<0.05^{*}$, $\mathrm{p}<0.005^{* *}, \mathrm{p}<0.0005^{* * *}$

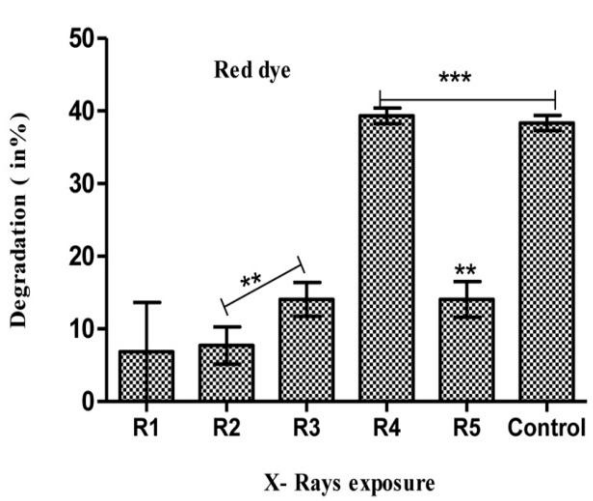

(A)

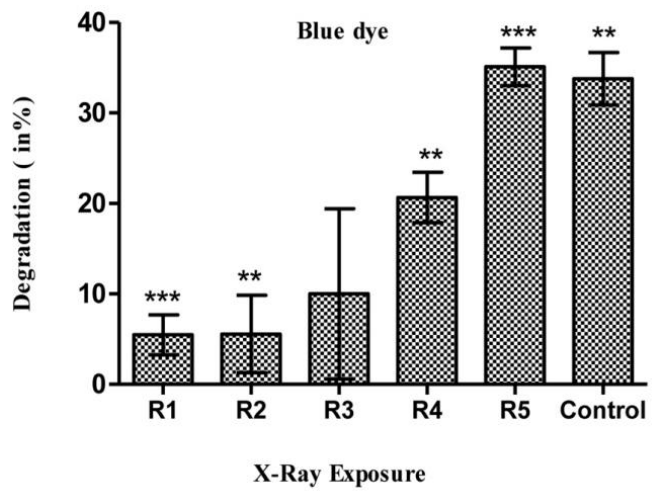

(B)

Fig.2 Mutagenesis with X-rays (A) red dye and (B) blue dye

'Bars' represent the mean $\pm \mathrm{SE}$ from three independent experiments, 'star' indicates significant difference at $\mathrm{p}<0.05^{*}$, $\mathrm{p}<0.005^{* *}, \mathrm{p}<0.0005^{* * *}$

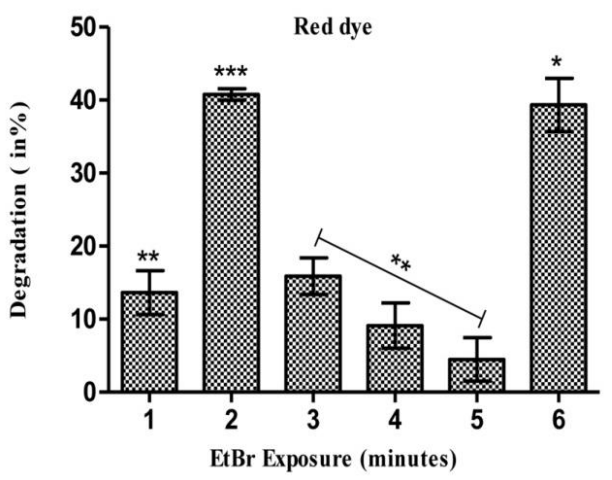

(A)

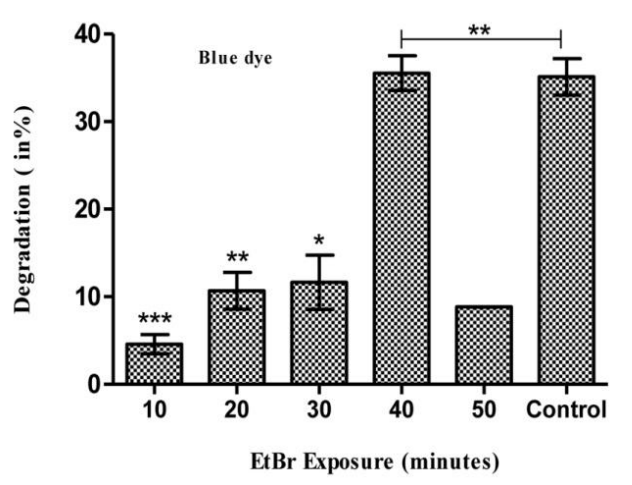

(B)

Fig.3 Mutagenesis with ethidium bromide treatment(A) red dye and (B) blue dye

'Bars' represent the mean $\pm \mathrm{SE}$ from three independent experiments, 'star' indicates significant difference at $\mathrm{p}<0.05^{*}$, $\mathrm{p}<0.005^{* *}, \mathrm{p}<0.0005^{* * *}$ 
Int.J.Curr.Microbiol.App.Sci (2020) 9(3): 1987-1997

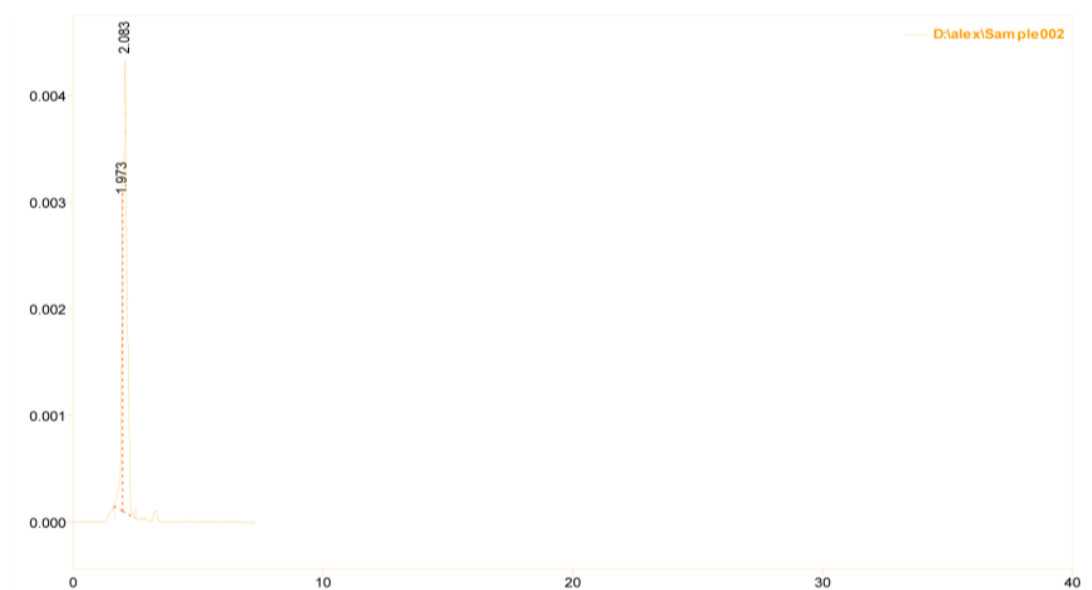

(A)

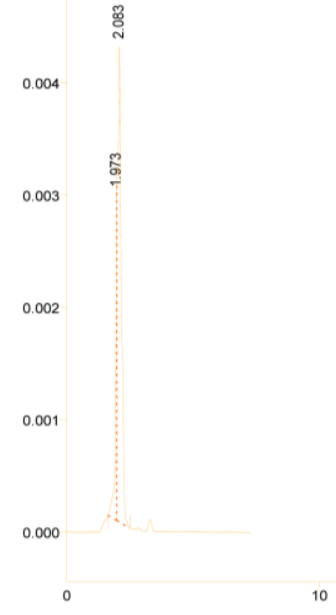

D:lale xiSam ple 002

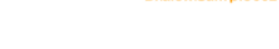

30

$\underset{[m i n,]}{40}$

(B)

Fig.4 High performance liquid chromatography (HPLC) analysis Red dye (A) control (B) sample

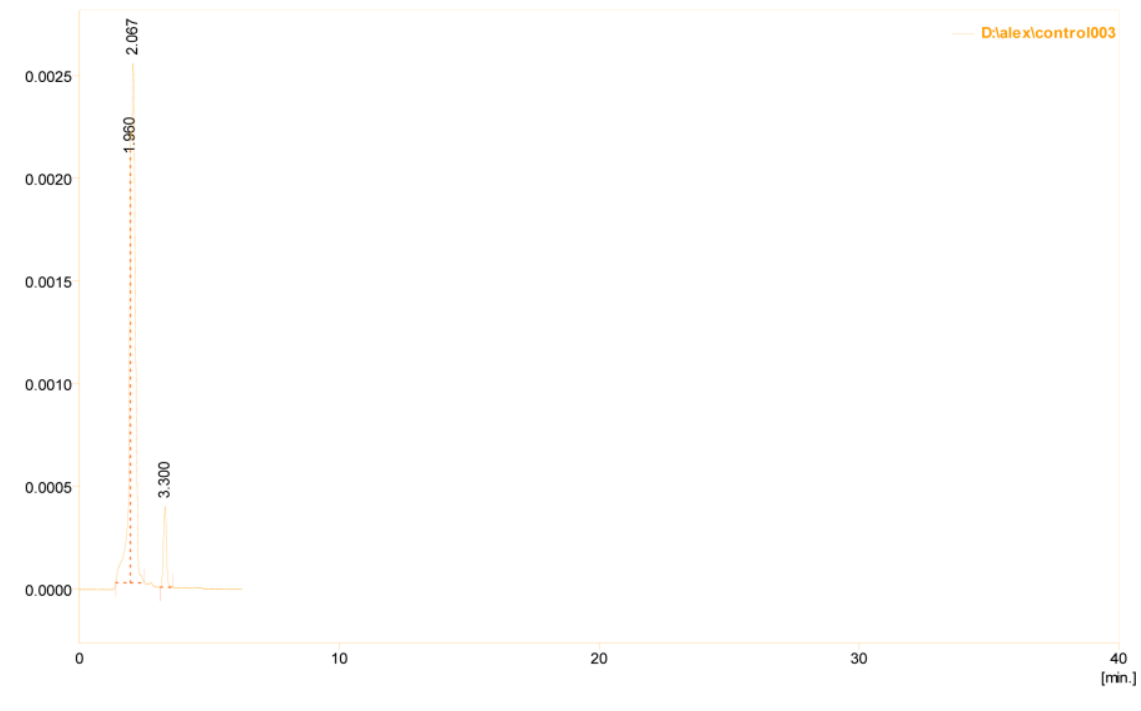




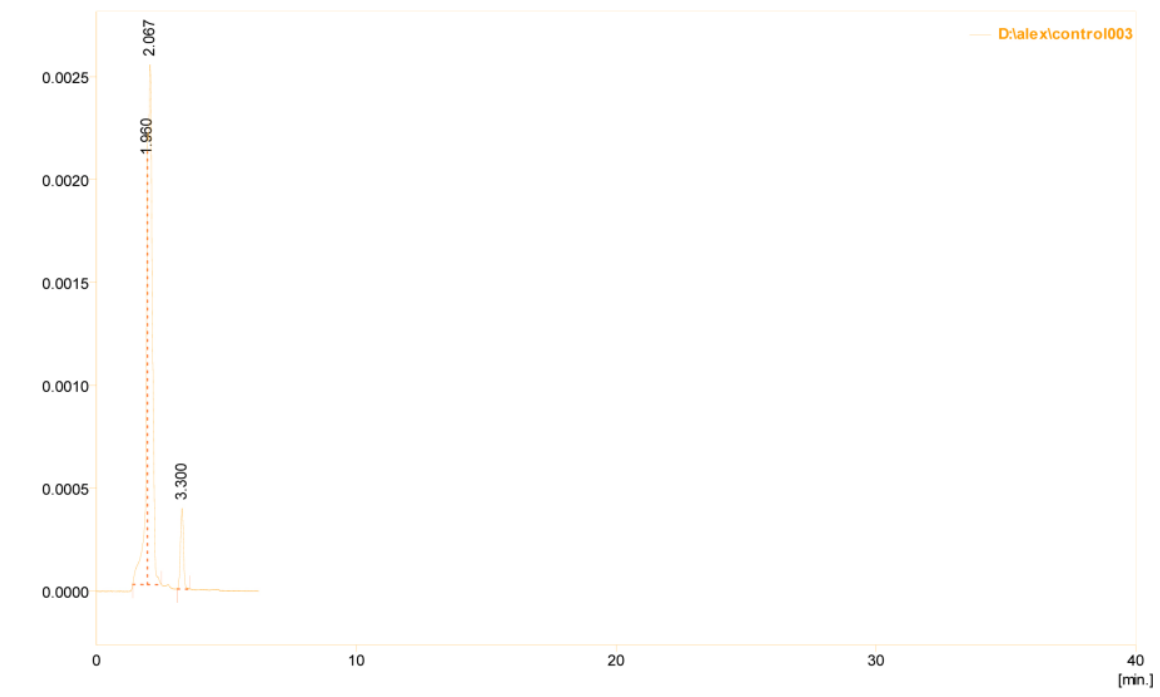

(A)

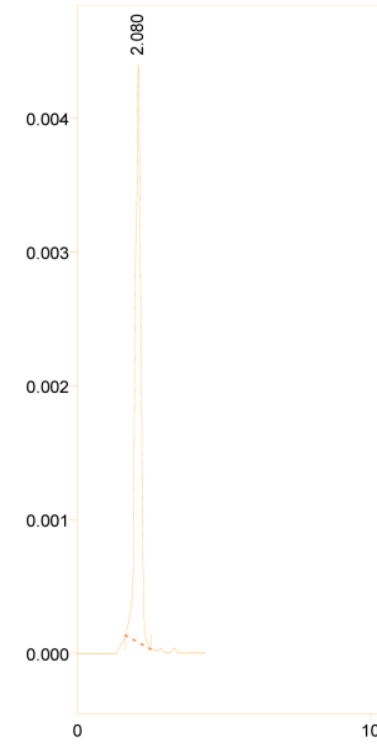

10

20

30

(B)

Fig.5 High performance liquid chromatography (HPLC) analysis Bluedye (A) control (B) sample

The present study showed that, mutagenesis of bacteria by UV radiation increases the degradation ability of native bacterial isolates. In this present study, the mutant strains of Bacillus species exhibited higher degradation than its wild strains.

This study reflected that, gene specific mutation enhanced the degradation ability of bacteria and can be used for the development of novel remediation strategies. The growth and azo dye degradation capacity of the isolated strain was examined and compared with the mutated strain.

The overall purpose of this study was to demonstrate the effectiveness of and the pathway used for dye degradation in the isolated strain and its mutant variant. 


\section{Acknowledgement}

Authors are thankful to the Head of Department of P. G. Studies and Research in Environmental Science, Kuvempu University, Jnanasahyadri, Shankaraghatta, Shivamogga (Karnataka), India.

\section{References}

AlsNielsen J. and McMorrow, D. (2011). Elements of modern X-ray physics: John Wiley \& Sons.1-30.

Alsulami, A.A., Altaee, A. M. R., Al-Kanany, F. N. A. (2014). Improving oil biodegradability of aliphatic crude oil fraction by bacteria from oil polluted water, African Journal of Biotechnology. 13(11): 1243-1249.

Baltz, R.H. (1986). Strain improvement. In: Manual of industrial Microbiology and Biotechnology. Demani, A. L. and Solomon, N. A. (eds.) American Society for Microbiology, Washington D.C. $84-190$.

Chaudhari, T.D. and Fulekar, M.H. (2013). Strain improvement of Pseudomonas pseudoalcaligenesMHFENV for degradation of di-butyl phosphate, strategies and methods, International Journal Advances Research Technology.2(7): 380-399.

Chen J., Q. Yang, T. Huang, T., Zhang, Y., Ding, R. (2011). Enhanced bioremediation of soil contaminated with viscous oil through microbial consortium construction and ultraviolet mutation, World Journal Microbiology Biotechnology, 27(6):1381-1389.

Feinendegen, L. (2014). Evidence for beneficial low level radiation effects and radiation hormesis. TheBritish Journal of Radiology.78 (925): 3-7.

Galhardo, R.S., Hastings, P.J., Rosenberg, S. M. (2007). Mutation as a stress response and the regulation of evolvability,
Critical Reviews in Biochemistry and Molecular Biology, 42: 399-435.

Hall, E. J. and Giaccia, A. J. (2006). Radiobiology for the Radiologist: Lippincott Williams \& Wilkins. 546.

Hopwoods D.A. (1970). Isolation of mutants, In: Methods in Microbiology (Morris J.R. and D.W. Ribbons eds.), Academic Press, London, 3A: 363 - 424.

Kumar, N. S., Manoharan, N., Ganesan, S., Manivannam, S. P., Velsang, G. (2010). Isolation, screening and in mutational assessment of indigenous soil bacteria for enhanced capability in petroleum degradation, International Journalof EnvironmentalSciences. 1(4): 498-512.

Lederberg, J. and Lederberg, E. M. (1951). Replica plating and Indirect selection of bacterial mutants, Journal of Bacteriology. 63, 3:399-406.

Macgregor, J.T. and Johnson I. J. (1977).In vitro metabolic activation of ethidium bromide and other phenanthridinium compounds: mutagenic activity in Salmonella typhimurium.Mutation Research.48(1):103-107.

Madhuri, T., Indrani, V., Devi, P. S. (2018). Analytical Biodegradation of Azo Dye (Remazol Red RB) by Bacillus cereus.Journal of Chemical and Pharmaceutical Research.10(4): 74-80.

Mandalaywala, H. P. and Trivedi, R. (2016). Effective microbial consortium of bacterial isolated from hydrocarbon polluted soil of Gujarat, India, Journal of Advanced Researchin Biotechnology. 1(1): 1-9.

Okafor, N. (1987).Industrial Microbiology, University of IFE Press Ltd., Ile-Ife, Nigeria, pp. 90-99.

Ohta, T., Tokishita, S., Yamagata, H. (2001). Ethidium bromide and SYBR green I enhance the genotoxicity of UVirradiation and chemical mutagens in $\mathrm{E}$. coli, Mutation Research. 492: 91-97.

Partila A.M. (2013). Biodegradation of 
Polycyclic Aromatic Hydrocarbons in Petroleum Oil Contaminating the Environment, Ph.D. Thesis, Cairo University, Egypt.

Pushpa, V., Yogendra, K., Mahadevan, K.M., Mahesh, M. (2019).Isolation and identification of azo dye degrading microbes using 16s rRNA sequencing.Journal of Applied and Natural Sciences. 11(2):245-249.

Rajeshwari K., R. Subashkumar, R., Vijayaraman, K. (2011). Biodegradation of mixed textile dyes by bacterial strain isolated from dye waste effluent, Research Journalof Environmental Toxicology. 5: 97-107.

Robertson K .L., Mostaghim, A., Cuomo, C. A., Soto, C. M., Lebedev, N. (2012) Adaptation of the Black Yeast Wangielladermatitidis to Ionizing Radiation: Molecular and Cellular Mechanisms. Plos One 7(11): e48674.
Ristow, M. and Schmeisser, S. (2011). Extending life span by increasing oxidative stress. Free Radical Biology and Medicine. 51(2): 327-36.

Rowland, T. D., Kending, H. L., Jones, R. G. (1984). Improving efficiency and coverage in survey research on the aged. Australian Journal on Aging. 3, 2: 34-38.

Saghatchi, F., Jafari, G. A., Taran, J., Farahmandkia, Z. (2016). The Impact of Low Level X-rays on Biosynthesis of Gold Nanoparticles by Actinobacteria. J. Hum. Environ. Health Promot2, 1:3238.

Singer V.L., Lawlor, T.E. Yue, S. (1999). Comparison of SYBR green I nucleic acid gel stain mutagenicity and ethidium bromide mutagenicity in the Salmonella/mammalian microsome reverse mutation assay (Ames test), Mutation Research. 439(1) : 37-47.

\section{How to cite this article:}

Pushpa. V., K. Yogendra, K. M. Mahadevan and Mahesh. M. 2020. Enhancement of Azo Dye Degradation by Chemical and Physical Mutagenesis in Identified Bacillus: An Influential Source of Industrial Dye Degradation. Int.J.Curr.Microbiol.App.Sci. 9(03): 1987-1997. doi: https://doi.org/10.20546/ijcmas.2020.903.231 